\section{Photooxidation of the Diaquodimercury(I) Cation}

\section{ARND VOGLER* and HORST KUNKELY \\ Institut für Anorganische Chemie, Universität Regensburg, Universitätstrasse $31, D .8400$ Regensburg (F.R.G.)}

(Received March 8, 1989; revised April 26, 1989)

The cation $\mathrm{Hg}_{2}{ }^{2+}$ may be regarded as the simplest binuclear complex that contains a metal-metal single bond. This bond consists of an electron pair in a $\sigma$ bonding MO which is formed by the interaction of the $6 s$ orbitals of both mercury ions [1]. While in numerous studies it has been shown that metal-metal single bonds of binuclear transition metal complexes can be split homolytically by $v^{*}$ excitation $[2,3]$, the photochemistry of $\mathrm{Hg}_{2}{ }^{2+}$ is virtually unexplored to our knowledge. We present here the first results on the photoreactivitiy of $\mathrm{Hg}_{2}{ }^{2+}$. Our study was stimulated partially by Mason [1], who assigned electronic transitions to absorption bands in the spectrum of $\left[\mathrm{Hg}_{2}\left(\mathrm{H}_{2} \mathrm{O}\right)_{2}\right]^{2+}$ and raised the question of whether the $\sigma \sigma^{*}$ state of the $\mathrm{Hg}_{2}{ }^{2+}$ moiety is an unbound state which may lead to a dissociation.

The electronic absorption spectrum of $\left[\mathrm{Hg}_{2}\right.$ $\left.\left(\mathrm{H}_{2} \mathrm{O}\right)_{2}\right]^{2+}[1]$ in diluted $\mathrm{HClO}_{4}(0.01 \mathrm{M})$ is dominated by a very broad and intense band in the UV (Fig. 1) at $\lambda_{\max }=237 \mathrm{~nm}(\epsilon=27600)$. The complex did not show any luminescence $\left(\lambda_{\text {exc }}=250 \mathrm{~nm}\right)$ in deaerated aqueous solutions at room temperature or in ethanol glasses at $77 \mathrm{~K}$. Light absorption by

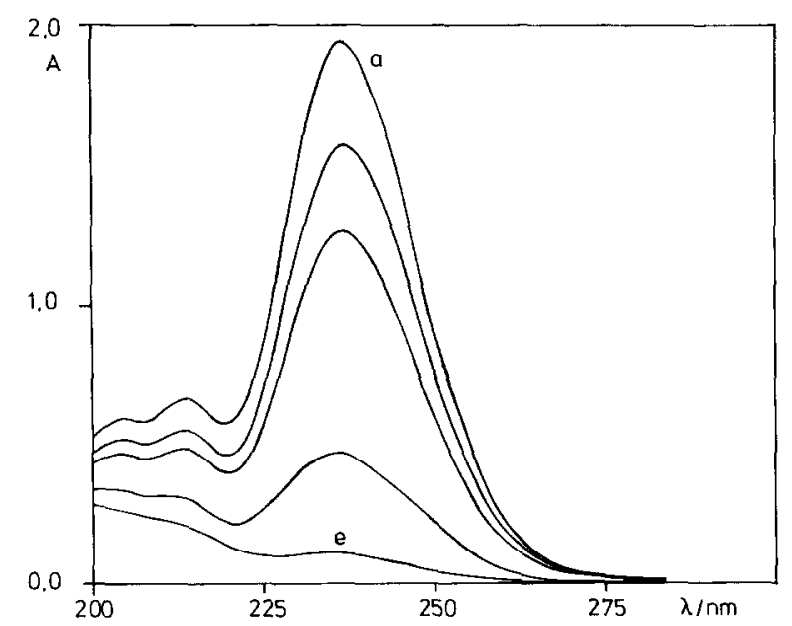

Fig. 1. Spectral changes during the photolysis of $7.03 \times 10^{-5}$ $\mathrm{M} \mathrm{Hg}_{2}\left(\mathrm{ClO}_{4}\right)_{2} \cdot 4 \mathrm{H}_{2} \mathrm{O}$ in $0.01 \mathrm{M} \mathrm{HClO}_{4}$ at (a) $0,1,2,5$, and (e) $10 \mathrm{~min}$ irradiation time, with whitc-light irradiation (Osram HBO $100 \mathrm{~W} / 2 \mathrm{lamp}$ ) and a 1 -cm cell.

*Author to whom correspondence should be addressed. aqueous $\left[\mathrm{Hg}_{2}\left(\mathrm{H}_{2} \mathrm{O}\right)_{2}\right]^{2+}$ was not associated with a permanent chemical change if the solution was saturated with argon. However, in air-saturated solutions a rather efficient photolysis was observed, as indicated by the spectral changes which accompanicd the irradiation (Fig. 1). The UV band of $\left[\mathrm{Hg}_{2}\right.$ $\left.\left(\mathrm{H}_{2} \mathrm{O}\right)_{2}\right]^{2+}$ disappeared; $\mathrm{Hg}(\mathrm{I})$ was apparently photooxidized to $\mathrm{Hg}(\mathrm{II})$. The spectrum of the photolyzed solution was very similar to that of $\mathrm{Hg}\left(\mathrm{ClO}_{4}\right)_{2}$ in diluted $\mathrm{HClO}_{4}(\sim 0.01 \mathrm{M})$. The formation of $\mathrm{Hg}(\mathrm{II})$ was confirmed by a qualitative analysis. While the addition of iodide to aqueous $\left[\mathrm{Hg}_{2}\left(\mathrm{H}_{2} \mathrm{O}\right)_{2}\right]^{2+}\left(\sim 10^{-4}\right.$ M) was accompanied by the precipitation of greenish yellow $\mathrm{Hg}_{2} \mathrm{I}_{2}$, the photolyzed solution yielded a red precipitate of $\mathrm{HgI}_{2}$. The irradiation led also to an increase in the $\mathrm{pH}$. In addition, $\mathrm{H}_{2} \mathrm{O}_{2}$ was formed as a photoproduct. It was detected by a qualitative test for peroxide (Merckoquant 10011). The progress of the photolysis was monitored by measuring the extinction at the band maximum at $237 \mathrm{~nm}$ where the absorption of the photoproduct is negligible. The quantum yield for the disappearance of $\left[\mathrm{Hg}_{2}\left(\mathrm{H}_{2} \mathrm{O}\right)_{2}\right]^{2+}$ was $\phi=0.05$ at $\lambda_{\text {irr }}=254 \mathrm{~nm}$.

The frontier orbitals of $\left[\mathrm{Hg}_{2}\left(\mathrm{H}_{2} \mathrm{O}\right)_{2}\right]^{2+}$ are generated by the $\sigma$ interaction of the $6 s$ orbitals of mercury [1]. The metal-metal bond of $\mathrm{Hg}_{2}{ }^{2+}$ is formed by the occupation of the bonding $3 \sigma_{\mathrm{g}}{ }^{+}$ orbital. The $3 \sigma_{u}{ }^{+}$orbital is the corresponding antibonding combination. The intense absorption band of $\left[\mathrm{Hg}_{2}\left(\mathrm{H}_{2} \mathrm{O}\right)\right]^{2+}$ at $\lambda_{\max }=237 \mathrm{~nm}$ is then assigned to the ${ }^{1} \Sigma_{\mathrm{g}}{ }^{+} \rightarrow \Sigma_{\mathrm{u}}{ }^{+}\left(\mathrm{a}^{1} \Sigma_{\mathrm{u}}{ }^{+}\right)$transition which involves the promotion of an electron from the $3 \sigma_{\mathrm{g}}{ }^{+}$to the $3 \sigma_{\mathrm{u}}{ }^{+}$ orbital [1]. On the basis of our observations, we suggest that the $\sigma \sigma^{*}$ state of $\left[\mathrm{Hg}_{2}\left(\mathrm{H}_{2} \mathrm{O}\right)_{2}\right]^{2+}$ is indeed dissociative:

$\mathrm{Hg}_{2}{ }^{2+} \stackrel{\mathrm{h} \nu}{\longrightarrow} 2 \mathrm{Hg}^{+}$

In the absence of oxygen, the $\mathrm{Hg}^{+}$radical ions regenerate $\mathrm{Hg}_{2}{ }^{2+}$. In air-saturated solutions, $\mathrm{Hg}^{+}$is intercepted by oxygen

$2 \mathrm{Hg}^{+}+\mathrm{O}_{2}+2 \mathrm{H}^{+} \longrightarrow 2 \mathrm{Hg}^{2+}+\mathrm{H}_{2} \mathrm{O}_{2}$

As an alternative our results can be also explained by another mechanism which in our opinion is less likely to be operative. Electronically excited $\left({ }^{*}\right)\left[\mathrm{Hg}_{2}\right.$. $\left.\left(\mathrm{H}_{2} \mathrm{O}\right)_{2}\right]^{2+}$ may be oxidized directly by oxygen

$\mathrm{Hg}_{2}{ }^{2+*}+\mathrm{O}_{2}+2 \mathrm{H}^{+} \longrightarrow 2 \mathrm{Hg}^{2+}+\mathrm{H}_{2} \mathrm{O}_{2}$

However, the absence of any luminescence of $\left[\mathrm{Hg}_{2}\left(\mathrm{H}_{2} \mathrm{O}\right)_{2}\right]^{2+}[4]^{\dagger}$ supports the suggestion that the primary photochemical step involves a homolytic cleavage of the metal-metal bond [5]. More experi-

\footnotetext{
† Some $\mathrm{Hg}(\mathrm{I})$ halides such as $\mathrm{Hg}_{2} \mathrm{Cl}_{2}$ show a strong orange or green luminescence [4]. However, this emission is apparently a solid-state effect and not a molecular property.
} 
mental work, especially the detection of $\mathrm{Hg}^{+}$as intermediate, is required to distinguish between both mechanisms. Further studies of this subject are in progress.

\section{Acknowledgements}

Financial support for this research by - the Deutsche Forschungsgemeinschaft and the Fonds der Chemischen Industrie is gratefully acknowledged.

\section{References}

1 W. R. Mason, Inorg. Chem., 22 (1983) 147.

2 G. L. Geffroy and M. S. Wrighton, Organometallic Photochemistry, Academic Press, New York, 1979.

3 T. J. Meyer and J. V. Caspar, Chem. Rev., 85 (1985) 187.

4 J. B. Gallivan and S. K. Deb, J. Lumin., 6 (1973) 77.

5 A. E. Stiegman and V.M. Miskowski, J. Am. Chem. Soc., 110 (1988) 4053. 